\section{Sudden oak death genome mapped}

The entire DNA blueprint for Phytophtora ramorum the pathogen that causes sudden oak death - has been sequenced, scientists with the Joint Genome Institute (JGI) announced in June. The nonprofit institute is operated by UC for the U.S. Department of Energy.

Mature oak trees began mysteriously dying from sudden oak death in the mid-1990s; UC scientists identified and diagnosed P. ramorum as the culprit in 2000. JGI scientists, who collaborated with the Virginia Bioinformatics Institute, announced that P. ramorum has 16,000 genes and 60 million chemical DNA units (base pairs). (Humans have 25,000 to 30,000 genes and 2.9 billion base pairs.)

Concurrently, JGI announced the sequencing of Phythophthora sojae, which causes root rot in soybeans. The genome sequences are expected to help scientists develop rapid detection systems and methods to control the spread of sudden oak death, which has killed tens of thousands of trees, and the soybean disease, which causes an estimated $\$ 1$ billion in crop losses annually.

As of June, P. ramorum had been found in 13 California counties and southern Oregon, as well as 125 nurseries in 17 states nationwide. In April, wood rose (Rosa gymnocarpa), a native California flower commonly found in a variety of habitats and a popular ornamental, was added to the list of about 30 reg- death. ulated P. ramorum host plants.

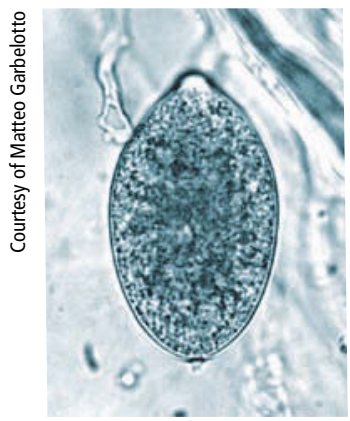

Phytophtora ramorum, the pathogen that causes sudden oak

\section{No safe place to sit in tick-infested forests}

Resting on a log or leaning against a tree in California's tick-infested hardwood forests can increase the risk of acquiring ticks harboring the Lyme disease bacterium, UC Berkeley researchers found.

"We sat on logs for only five minutes at a time, and in 30\% of the cases, it resulted in exposure to ticks," said Insect Biology professor Robert Lane. "The next riskiest behavior was gathering wood, followed by sitting against trees, which resulted in tick exposure $23 \%$ and $17 \%$ of the time."

The study, published in the March Journal of Medical Entomology, is the first quantitative analysis of human behaviors that may increase the risk of tick exposure in California's hardwood forests. Lane and study co-author Denise Steinlein, a UC Berkeley graduate student in insect biology, conducted the research at the UC Hopland Research and Extension Center in southeastern Mendocino
County. UC Berkeley research specialist Jeomhee Mun is also a co-author.

The western black-legged tick, found primarily in the far western United States as well as British Columbia, is the primary carrier of the corkscrewshaped spirochete Borrelia burgdorferi, which is responsible for Lyme disease (see California Agriculture 55[6]:13-8).

The young nymphal ticks that generally spread Lyme disease are notoriously difficult to detect. California's nymphal tick season begins in early

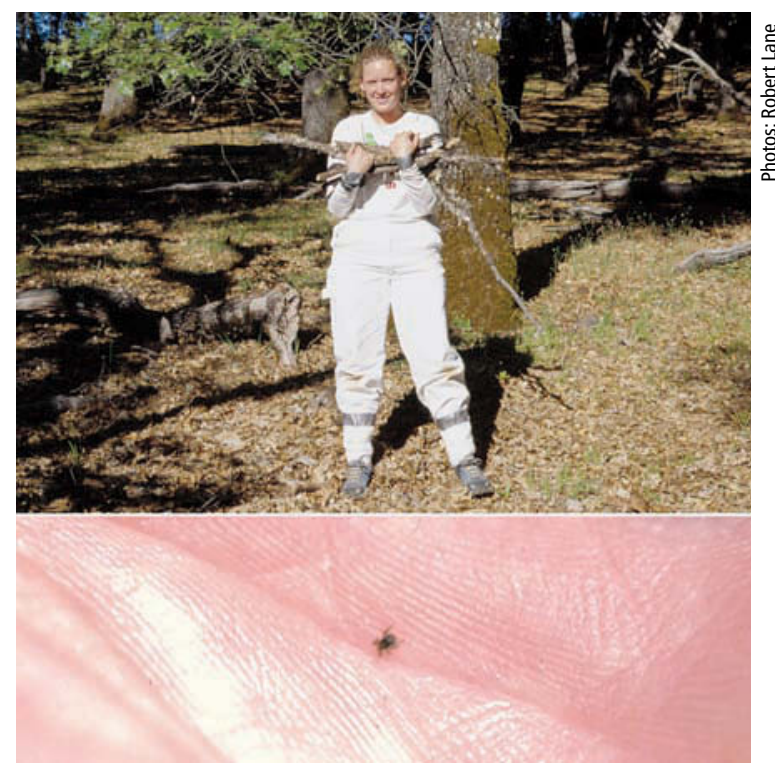

The researchers wore white clothing from head to toe, and engaged in a series of typical outdoor activities to attract ticks, such as sitting on logs and leaning against trees. Top, Denise Steinlein carries wood at the tickinfested UC Hopland Research and Extension Center. Bottom, the nymphal stage of the western blacklegged tick, which can carry the spirochete that causes Lyme disease, is the size of a poppy seed. spring and continues into summer.

DNA tests revealed that $3 \%$ to $4 \%$ of the ticks the researchers found on their bodies, as well as by sampling leaf litter with a white flannel cloth, tested positive for B. burgdorferi and another, less prevalent human disease-causing bacterium, Anaplasma phagocytophilum.

\section{West Nile virus spreads}

As of June 22, California health officials had confirmed seven human cases of West Nile virus (WNV) in 2004, including a 61-year-old San Bernardino County man hospitalized with encephalitis. The virus, which is transmitted from birds to mosquitoes to humans (or horses), has also been confirmed in nearly 500 dead birds in Los Angeles, Riverside, San Bernardino and Ventura counties.

"What the dead birds are telling us is that there's a lot of virus circulating out there," says John Edman, director of the UC Davis Center for Vectorborne Diseases (UCD/CVB). "We're in a high state of alert."

UC Davis scientists are collaborating with the California Department of Health Services, California Department of Food

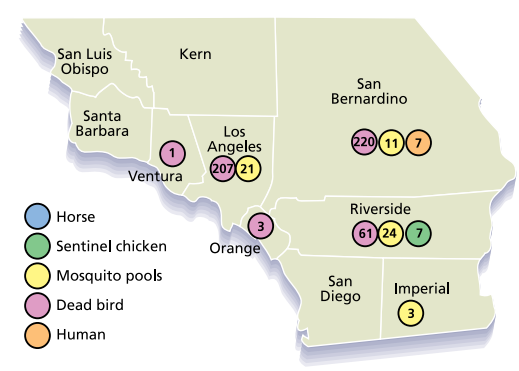

As of June 22, 2004, California's surveillance network had detected West Nile virus in humans; dead birds; aggregate pools of mosquitoes; and sentinel chickens, which have their blood drawn and tested biweekly. No infected horses have been found. Source: www.westnile.ca.gov 
and Agriculture, local mosquito and vector control districts, and other agencies on a statewide surveillance program for WNV. The UCD/CVB biocontainment laboratory tests tissues from all reported dead birds, blood from sentinel chickens (in 232 flocks of 10 each), and pools of 50 mosquitoes each gathered from nearly 3,000 traps around the state (see figure, page 133).

The risk of serious illness from WNV in humans is low, with the elderly, the young and those with compromised immune systems at greatest risk. While most infected individuals will not experience any illness or only mild symptoms, some of those infected will develop serious neurological symptoms such as encephalitis or meningitis. In 2003,
9,862 WNV cases were reported to the U.S. Centers for Disease Control nationwide, with 264 deaths.

Statewide, the UC Division of Agriculture and Natural Resources funds the Mosquito Research Program, which provides grant support for UC research projects that investigate the vectors of WNV and other mosquito-borne diseases and seek environmentally safe methods to improve mosquito management. Likewise, about 40 members of the UC Mosquito Research and Extension Workgroup are working together to establish research priorities and seek extramural funding to pursue additional WNV-related research. - Editors (As we went to press, the number of human cases in California continued to climb, totalling 17 on July 10.)

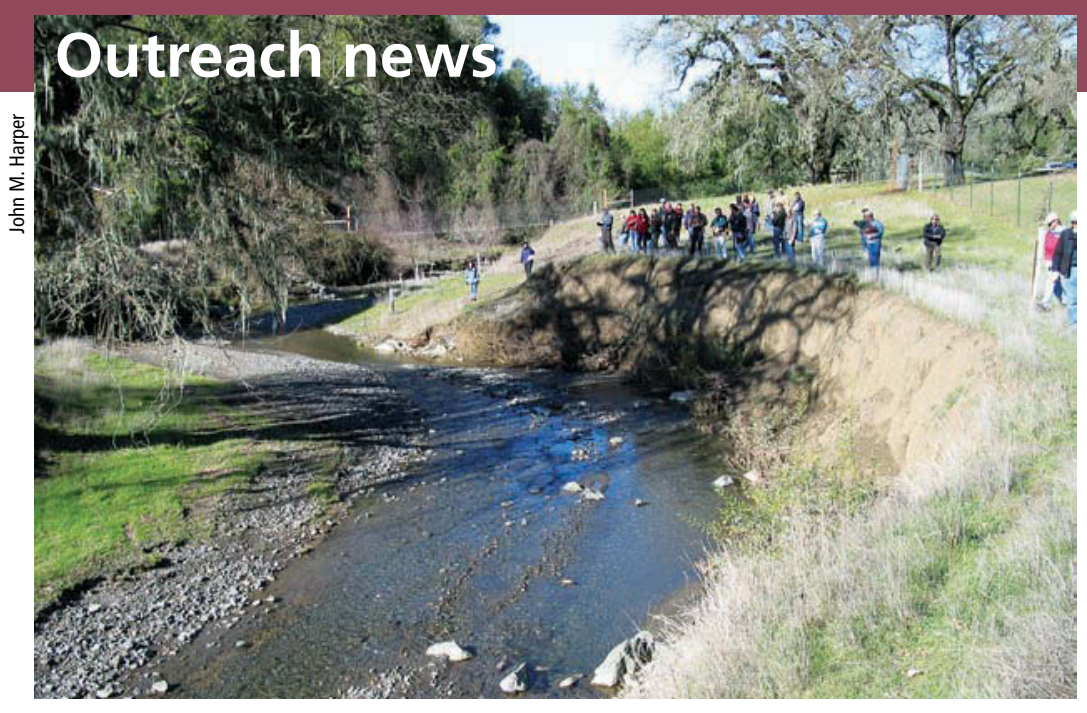

Water-quality short course participants evaluate a sediment source site (bankcutting) along Parson's Creek using the Sediment Inventory Method, at the UC Hopland Research and Extension Center in Mendocino County.

\section{Courses belp ranchers, farmers mitigate water-quality impacts}

Oost of the water-quality problems in the 1 United States are from runoff, and in many places much of this nonpoint source pollution in rivers and lakes comes from agriculture, according to the U.S. Environmental Protection Agency (EPA). Ranching and farming practices can degrade streams and coastal waters with nonpoint source pollutants such as sediment, heat and nutrients (see pages 138 to 163). This degradation can threaten salmon, which need cold, clear water for spawning.

In 1989, the range livestock industry recognized that it needed to address water quality and asked UC for help. "The industry knew regulation was coming," says Melvin George, UC Cooperative Extension (UCCE) rangeland management specialist.

In 1994, the UCCE Rangeland Watershed Program began working with ranchers and state agencies to develop the Ranch Water Quality Management Planning Shortcourse, which helps ranchers develop voluntary plans for managing water quality on their land. "The beauty of it is that landowners can make their own decisions so they don't have a regulatory agency come and tell them what to do," says George, who helped develop the short course.

Landowners in watersheds with rivers listed as impaired by the EPA must help meet total maximum daily load (TMDL) regulations, which stipulate how much pollution bodies of water can receive and still meet water-quality standards.

The ranch water-quality short course entails about 10 to 15 hours of classroom and field instruction, including clean water laws; monitoring pollution sources; and management of nonpoint source pollution, such as sediment from cattle grazing and trampling, heat from decreased riparian vegetation, and nutrients and pathogens from manure. The short course culminates in developing individualized ranch water-quality management plans that identify and prioritize water-quality problems and outline how to address them.

The short course has had more than 60 sessions attended by more than 800 ranchers from 31 counties, and by mid-2004 had resulted in plans covering 1.3 million acres of rangeland. A 2002 survey of participants showed that $60 \%$ had completed a plan in class and $67 \%$ had implemented at least one 